\title{
Kernos
}

Revue internationale et pluridisciplinaire de religion grecque antique

$4 \mid 1991$

Varia

\section{What is Greek about Greek Mythology?}

\section{David Konstan}

\section{OpenEdition}

\section{Journals}

\section{Electronic version}

URL: http://journals.openedition.org/kernos/280

DOI: 10.4000/kernos.280

ISSN: 2034-7871

\section{Publisher}

Centre international d'étude de la religion grecque antique

\section{Printed version}

Date of publication: 1 January 1991

Number of pages: 11-30

ISSN: 0776-3824

Electronic reference

David Konstan, « What is Greek about Greek Mythology? », Kernos [Online], 4 | 1991, Online since 11 March 2011, connection on 01 May 2019. URL : http://journals.openedition.org/kernos/280 ; DOI :

10.4000/kernos.280 
Kernos, 4 (1991), p. 11-30.

\section{WHAT IS GREEK ABOUT GREEK MYTHOLOGY ?}

The paper that follows began as a lecture, in which I attempted to set out for a group of college teachers what was specific to Greek mythology, as opposed to the mythologies of other peoples ${ }^{1}$. Of course, there is no single trait that is unique to Greek myths. But there are several characteristics of Greek mythology that are, despite the intense attention it has received for decades and even centuries, still not commonly noticed in the scholarly literature, and which, taken together, contribute to its particular nature. By the device of contrasting with Greek myths a single narrative from a very different society, I thought that I might set in relief certain features that have by and large been overlooked, in part precisely because they are so familiar as to seem perfectly natural. My survey of the characteristics of Greek mythology, needless to say, makes no pretense to being exhaustive. I have remained content to elicit just those aspects - four, in all - that emerge from the contrast with the foreign tale I have selected. Nor have I sought, in this paper, to document fully the claims I am making for the peculiarity of Greek mythology. So far, I have not found significant exceptions to the very broad theses I shall be defending. But the present argument is in the nature of a preliminary sketch, and I shall be grateful whether for help in filling in the details, or for contradictory evidence that alters the image I have limned.

The following story is told among an Austronesian people who inhabit a relatively small island in eastern Indonesia called Sumba, located between Bali and Timor ${ }^{2}$. A woman was married to a rat (he sued for her hand, it must be conceded, in human form). The rat invited her to join him in his hole. Because she was pregnant, however, she was

1 The lecture was originally presented on 6 June 1989 to a Faculty Humanities Seminar at Prince George's Community College in Largo, Maryland, on "The Nature and Function of Greek Mythology", sponsored by a grant from the National Endowment for the Humanities; it was presented also on 17 November 1989 before the Department of Classics of Miami University in Oxford, Ohio.

2 I am indebted to my friend, Joel KUIPERs, of the Department of Anthropology at George Washington University in Washington D.C., for information about this tale which he recorded during his fieldwork in Sumba. I wish also to express my gratitude to him for his encouragement and thoughtful comments on every aspect of the present paper. 
too fat to fit through the opening. As a result, the rat was enraged and killed her. From her body there then grew all edible plants, with different foodstuffs, such as yams, wheat, or rice, emerging from specific parts, such as hands, feet, or belly. I may add that the story is recited at harvest time, in the evening.

We easily recognize this as an aetiological tale that explains the origin of things in the world, in this case, of botanical edibles, and it is no great leap to classify a story of this sort as a myth. And yet, when compared with Greek myths, which after all have given us the term, the Sumbanese narrative betrays certain odd features. To be sure, the Greeks had aetiological tales involving humans and animals in various combinations, as, for example, in the origin of several of the stellar constellations, such as Callisto - a woman who was turned into a bear, and then translated into the heavens. The story of a woman who marries a rat is not a great deal more strange than the metamorphosis of a woman into a bear. Both narratives presuppose a certain continuity or convertability between the animal and the human realms. Nevertheless, the Sumbanese tale is significantly different from the type of tale the Greeks were relating about the origins of the world during the period in which the myths we know were recorded, that is, from the end of the eighth century B.C. onwards, and it is on the nature of the differences that I shall focus now.

To begin with, the rat in the Sumbanese story is actually a rat-not, for instance, a human being in the guise of a rat, or transformed into one. While it makes an initial appearance in human form, in order, I suppose, to arouse the interest of the woman, it is clearly, as I am given to understand, a rat assuming the shape of a human, and not, as in the story of the frog prince, for instance, a human who is temporarily transformed into an animal. Now, in Greek mythology, humans do of course mate with animals, as in the case of the Minotaur, for example, who is the offspring of a union between Pasiphae, wife of Minos, and a prize bull. Perhaps it is a sign of the plasticity or visual character of the Greek imagination that there seems to be less of a disproportion between the relative bulk of the partners in this instance, as compared to marriage between a human being and a rat. But that is not, I think, the essence of the difference. The bull who is the father of the Minotaur is nothing other than a bull : a very handsome and alluring bull, but a bull all the same. That is to say, the bull does not speak, does not think as a 
human does, and accordingly does not, for example, contemplate wedlock with Pasiphae ${ }^{3}$. The Sumbanese rat, on the other hand, while it is not a human in rat's clothing, has human qualities, both mental and emotional. It evidently understands what marriage is, and is angry when its promised wife is unable to join him in his domicile. In Greek myths, on the contrary, when humans interact with animals, the animals are precisely animals, and the humans human. Boundaries may be crossed, but they are not obliterated in the way they seem to be in the narrative from Sumba.

Exceptions in Greek mythology will undoubtedly spring to mind, for example in the fables attributed to Aesop, where animals go about talking and acting like human beings both among themselves and, on occasion, with actual people as well, or the animal choruses in Old Comedy ${ }^{4}$. Some of the fables mention, by way of introduction, a time when humans and animals could converse together, and there is, incidentally, an analogous formula in Sumbanese about the time when the grass and the beasts could speak. Aesopian fables in the form in which we know them may be dated to the sixth century B.C. or thereabouts, and the type undoubtedly goes back long before that ${ }^{5}$. But

3 Ovid makes great sport over Pasiphae's preparations for her tryst with the bull, as though for a human partner; the joke is that her efforts are wasted, since the bull cannot appreciate them, cf. Ars amatoria, 1, 295-326, esp. 303-304: quo tibi, Pasiphae, pretiosas sumere uestes?/ ille tuus nullas sentit adulter opes.

4 In ARIsTophanes's Peace (127-128), Trygaeus claims to have found inspiration in Aesop for the idea of flying on a dung beetle. However, the relationship between Old Comedy and fable may well have been mediated by the iambic tradition, which was particularly hospitable to animal fables; see R.M. ROSEN, Old Comedy and the Iambographic Tradition, Atlanta, Scholars Press, 1988, p. 33-34. See also G. SIFAKIS, Parabasis and Animal Choruses : A Contribution to the History of Attic Comedy, London, Athlone Press, 1971, p. 78-85, for a review of ritual and anthropological theories concerning the origins of the animal choruses.

5 On the date of AEsor, see B.E.PERRY, Babrius and Phaedrus, Cambridge, 1965, XXXV-XLIII. Of AESOP's use of fables, PERRY remarks : "This exploitation of purely fictitious animal stories told orally in prose with comic effect, instead of theoretically historical myths ideally elaborated in poetry and song, was something new in the Greek world of the sixth century B.C., and that may account for Aesop's celebrity. Fables, as we have noted, are essentially metaphors, and metaphor as such was slow to make its appearance in early Greek literature.... It was with the increase of sophisticated ways of thinking, fostered by urban life in the new city-states, that the Aesopic fable came into its own gradually and attracted popular attention in the time of Aesop" (XLV). Perry's theory of fable as «a rhetorical device from the beginning" (XXII), and 
Aesop's tales are fables, and not myths. Whether one may, for one or another purpose, classify them as myths, proto-myths, or decayed myths, is not to the purpose ${ }^{6}$. They were understood by the Greeks (and are felt today) to be different from the kinds of tales that made up the corpus of myths, and the difference was constituted as a protocol of genre. They were narrated in prose, and did not make it into the canonical hexameter texts that contained and defined myths for the Greeks : the great epics like the Iliad and the Odyssey, the hymns, and the cosmogonic narratives such as Hesiod's Theogony ${ }^{7}$. Fabular tales were not invoked to explain the origins of the world, or of the gods. The very existence of a category of prose fable, as distinct from the category of myth, points to a cleavage in the narrative tradition of the Greeks that sets it apart from those traditions that do not apparently observe such a protocol of genre ${ }^{8}$.

«nothing more than an indirect and inexplicit way of saying something» (XXI), abstracts entirely from the narrative contents : "It is a mistake... to look for the origin of fable in the narrative materials out of which fables are made" (XXIII). But well before the time of AESOP, the development of the hexameter tradition of mythology had relegated to the medium of oral prose transmission (and to forms of verse especially close to prose, e.g. the iambic poetry of ARCHILOCHUS) a set of folk-tale motifs with origins in early near-Eastern literature (cf. PERRY, XXVII-XXXIV), with the result that the fable, as defined by PERRY, was naturally associated with specific kinds of contents. PERRY is mistaken to ignore the effect of other literary genres on the development of the fable. See G. NAGY, The Best of the Achaeans, Baltimore, 1978, p. 281-83, on the traditional character of the fable.

6 See the penetrating remarks of L. EDMunds, in Edmunds (ed.), Approaches to Greek Mythology, Baltimore, 1990, p. 240 : "there is no clear dividing line between myth and folktale... the same narrative elements may appear in both at the same time among the same people.... The fluid relationship between myth and folktale also removes two other common notions : that folktales are earlier than myths; that folktales are later than myths"; also p. 6-9.

7 Cf. Ileana Chirassi Colombo, La religione in Grecia, Bari, 1983, p. 29 : "L'apparizione della scrittura nella nuova forma alfabetica, non più destinata al solo uso amministrativo, fissa nel formulario delle prime dediche votive lo stereotipo di una religiosità tipo, che ha nella poesia esametrica il suo punto di riferimenton.

8 Elizabeth TrAUBE, of the Department of Anthropology at Wesleyan University, informs me per litteras that the Mambai, who inhabit part of the Indonesian island of Timor, «would not receive [the Sumbanese story summarized here] as a 'myth' (i.e. a 'trunk' story), but would probably classify it as what they call maer, which corresponds (again approximately) to 'fable'". Traube suggests that I thus woverstate the uniqueness of the Greek 'cleavage' in generic categories", and adds that "in the Malayo-Polynesian world, there is an 
The Greek gods themselves are essentially anthropomorphic, even if they have the capacity to transform themselves into animals or other items for special purposes, most often, it seems, in order to facilitate an act of seduction. The Greeks of course recognized hybrid creatures such as centaurs or satyrs, some of which, like Pan, were of the status of minor gods. They may remind us, perhaps, of Egyptian deities, part hawk or alligator or jackal, and part human, or again, of Indian gods such as the elephant Ganesha, but there is an important difference. Creatures like centaurs, satyrs, and sileni are animal below and human above, just the opposite of the Egyptian gods. Their heads and torsoes - and this is what distinguishes them from Ganesha as much as from Anubis - are distinctly human, or humanoid (allowing, e.g., for Pan's horns). The Minotaur, it is true, was sometimes represented as having the head of a bull on the body and shoulders of a human being, but the Minotaur did not normally function in narratives as a sentient creature. The Greeks of the classical age seem to have eschewed divinities or species that thought or spoke from the head of a beast. Achilles' talking horse in the Iliad is a self-conscious exception, and it gets to speak exactly once before the fates silence it forever ${ }^{9}$.

The Greek myths, as we know them, evidently underwent at some stage a homogenization or reduction that excluded certain types of character and action, or relegated them to the status of fable or folk-tale. Perhaps this is part of what lies behind Herodotus' claim concerning the Greeks, that «they did not know until yesterday and the day before, so to speak, where each of the gods came from, whether they all existed

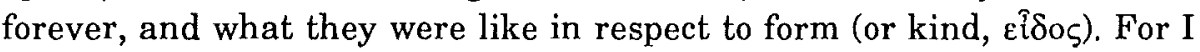
think that Hesiod and Homer are about four hundred years earlier than I am in age, and not more. These are the ones who created a theogony for

important distinction between poetic and prose traditions", and that often "origin stories come in two versions, one prose, usually involving interactions between human ancestors, animals, and so forth, and one poetic, in which the interactions are between more abstract figures». On Mambai myths, see Elizabeth TRAUBE, Cosmology and Social Life : Ritual Exchange among the Mambai of East Timor, Chicago, 1986.

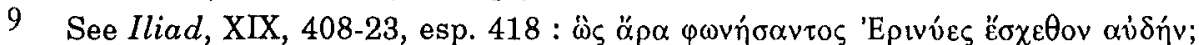
in Odyssey, X, 239-240, Odysseus' men lose the capacity for speech when they are converted by Circe into animals, though they retain their human

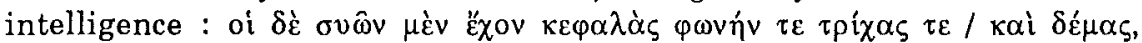

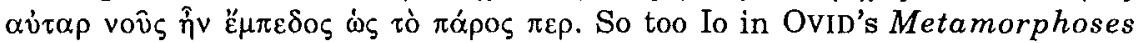
loses the power of speech when she is transformed into a cow, but uses her hoof to draw her name on the sand; in Apuleius' Metamorphoses, Lucius, having become an ass, is incapable of articulating human words. 
the Greeks, and gave the gods their particular names, distributed among them their functions and skills, and indicated their forms (or kinds)" (II, 53). I suspect that Herodotus may have meant by these remarks not just that Homer and Hesiod put the Olympian divinities and their complex relationships in order, but also that the epic and theogonic oral traditions set the rules, in a sense, for what might and might not count as mythology. We shall return to the matter of theogony. Here, we may note the special emphasis, apparently, on the shapes or forms ( $\left.\varepsilon{ }^{\prime} \delta \varepsilon \alpha\right)$ of the $\operatorname{gods}{ }^{10}$.

Anthropomorphism was to be a particularly strong feature of the deities that gained entry into the Greek pantheon. Those beasts that were enemies of the gods, such as the serpents Pytho and Typho, or the extraordinary boars, lions, hydras and the rest that tested the resources of Heracles, were exaggerated versions of real beasts : monstrously exaggerated, no doubt, but not endowed with qualities that would make them recognizably human, or divine. Thus, in Hesiod, Typho is described as bearing on his shoulders "a hundred fearsome snakeheads with black tongues flickering, and the eyes in his strange heads flashed fire under the brows; and there were voices in all his fearsome heads, giving out every kind of indescribable sound. Sometimes they uttered as if for the gods' understanding, sometimes again the sound of a bellowing bull whose might is uncontainable and whose voice is proud, sometimes again of a lion who knows no restraint, sometimes again of a pack of hounds, astonishing to hear; sometimes again he hissed; and the long mountains echoed beneath ${ }^{11}$. Voices there are, to be sure, but Typho seems rather to mimic other creatures, including the speech of the gods, than actually to be able to speak ${ }^{12}$. A few other odd creatures of an

10 In Heronotus, as well as in archaic Greek poetry, eidos signifies primarily shape or visible form, and it does not seem forced to suggest that HERODOTUS is referring here specifically to the anthropomorphic appearance of the gods.

11 Theogony, 825-35; the translation is that of M.L. WEST, transl., Hesiod : Theogony and Works and Days, Oxford, 1988, p. 27. In his great edition of the Theogony, Oxford, 1966. West comments ad v. 831 : «ڤ̋ $\sigma \tau \varepsilon \theta \varepsilon \circ \hat{\imath} \sigma \mathrm{r}$ : as if (speaking) to the gods.... This is Typhoeus' 'normal' voice. He makes the same kind of noise as a human larynx does..., though the language he speaks is of course that of the gods». This appears to be a different interpretation from that suggested by his translation, and which (if I understand him correctly) I have followed here (it is perhaps worth noting a minor discrepancy between the

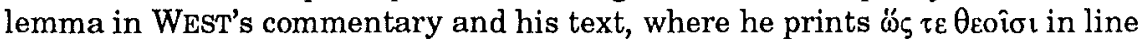
831).

12 The Greek philosophical tradition tended to emphasize the connection between rationality and speech; see, for the Stoics, DIOG. LAERT., VII, 51, and VARRO, De 
ambiguously monstrous status entered the mythological canon hundred-armed fellows, snake-haired Medusa, Argus of the many eyes - but all of them, I believe, are essentially human-like and humanheaded, however deformed. The division between anthropomorphic and theriomorphic remains more or less firm in the Greek myths.

A second feature of the Sumbanese story that seems to differentiate it from Greek myths is the image of the generation of all edible plants from the body of a woman. Greek creation narratives, whether in the form familiar from Hesiod or in the more obscure traditions such as the Orphic or Pythagorean ${ }^{13}$, do not put a comparable strain on our capacity to visualize the event. That the ocean gives birth to rivers, for example, seems a metaphorical way of saying that the sea generates or is the source of the brooks and streams that run upon the ground. We are not invited in the Hesiodic poems, for example, to contemplate or imagine rivers or mountains physically issuing forth from the womb or some other part of a god's body, as though by a process of conception and parturition. In part, the device of genealogical metaphor or allegory is facilitated by the Greek habit of associating a more or less anthropomorphic deity with natural objects that are revered ${ }^{14}$. Thus, the name Achelous identifies both a river, and a god with bull's horns but a

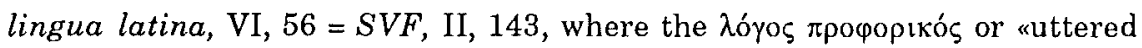
language" of birds (as opposed to $\lambda$ ó $_{\circ} \varsigma \dot{\varepsilon} v \delta\llcorner\alpha \theta \varepsilon \tau \varsigma$, which involves thought or concepts) is compared to the quasi-language of children; cf. SENECA, De ira, I, 3. I am indebted to J.-L. LABARRIÈRE's paper entitled Phantasia et logos chez les animaux : essai sur une polémique entre Stoïciens et Académiciens, presented at the Fifth Syposium Hellenisticum held in August 1989 at Syam, France.

13 See M.L. West, The Orphic Poems, Oxford, 1983, esp. p. 262-263 : «Orphic poetry had no special features that marked it off from other Greek poetry.... It was not enigmatic or mystical in tone.... Its mythology was not exclusive to it».

14 Cf. WEST, Theogony (above, n. 11), ad v. 777, on the idea that «the god of a spring or river lives in a house on the site" (with references). Also SOPHOCLES,

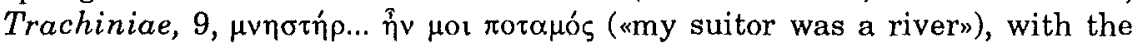
comment of P.E. Easterling (ed.), Sophocles Trachiniae, Cambridge, 1982, ad loc. : "Greek can say this without absurdity because potamos connotes both river and river god". For an elaborate comic treatment of the confusion between a god and the element or substance he metaphorically represents, see EurIPIDEs' Cyclops, 525-527, where Polyphemus expresses amazement that Dionysus inhabits a tiny flask; cf. D. KonSTAN, An Anthropology of Euripides' Kyklôps, in John J. WINkLER and Froma I. ZeITLIN (ed.), Nothing to Do with Dionysus? Athenian Drama in its Social Context, Princeton, 1990, p. 224. 
distinctly human visage, who, for example, engaged in, and lost, a wrestling match with Heracles for the possession of the bride Dejanira ${ }^{15}$. The Achelous, then, who is born from the union of the deities Ocean and Tethys (Theog., 337-40) is, on one level, a being whom we can readily imagine as the product of sexual congress between parents who are also more or less human in form. The genealogies in and of themselves are not so much the record of the creation of the natural world, as of the creation of those gods who represent, are an aspect of, dwell in, or exist in some kind of symbiotic relationship with the sacred objects around us.

Moreover, once the genesis of the gods is understood in this way, it becomes easier to think of divine procreation not as a literal description of the way in which the natural world comes into being, but rather as an allegory or symbolic representation of the creation of the cosmos. On the one hand, rivers appear upon the earth, fed by the encompassing waters; on the other hand, this process is represented as the birth of river gods from a mother goddess associated as consort with the god Ocean. The rivers do not themselves, however, emerge from a body imagined as female and human in form, somehow spurting from the flesh. The two aspects, divine and natural, that are united under the name, e.g., of Achelous, are kept distinct ${ }^{16}$.

Given this distinction, then, between indwelling gods and their genealogies, on the one hand, and the cosmos with its own history, on the other hand, in which natural objects come into being, we can, perhaps, understand how the Greek mythic narratives themselves provided something of the intellectual impetus that gave rise to physical philosophy among the Greeks. If divine births are not in themselves an explanation of the origins of natural things, but rather a kind of parallel narrative, placing in relation to one another the divinities that inhabit and represent the world of nature, then the way is clear to look for another set of explanations for the creation of the universe that conforms to the workings of natural objects themselves. Thus, the role assigned in

15 Cf. SopH., Trach., 9-27, with the comments by EASTERLING (above, n. 14) ad 1014 and 12-14 (p. 73-75) : in art, Achelous in his various metamorphoses is invariably represented with a human face.

16 Phillip Mitsis of the Department of Classics at Cornell University reminds me that in ARISTOPHANES' Clouds, Strepsiades supposes that rain occurs when Zeus urinates through a sieve (373), and thunder when he farts (293-94, cf. 385 94). This is a joke at Strepsiades's expense, of course, but even so, Strepsiades imagines a perfectly naturalistic relation between divine cause and visible effect; he does not think of Zeus as having a watery body. 
a couple of places in the Iliad, and more systematically perhaps in certain Orphic cosmologies, to Ocean and his wife Tethys as the progenitors of all the gods, becomes an allegory for the creative function of water ${ }^{17}$. Water, then, may be seen, as it apparently was seen by Thales, as the source of all things. However, the way in which water generates other things was not construed by Thales on the model of human parturition, but rather according to processes specific to water as an element. In the same way, it would seem, Thales' successor Anaximenes, who claimed that air was the origin of all things, explained that the different elements arose out of air by means of the condensation or rarefaction of the gaseous medium ${ }^{18}$.

As far as I can judge, the Sumbanese story opens up no such space between the woman who is the wife of the rat, and the body that generates the plant world. There are not two figures here, the earth, say, construed as female, and the human-like female who stands for the earth in a genealogical narrative. Rather, there is the single person of the woman, who is simultaneously the wife of the rat, until the time of her death at its hands (or paws), and the genetrix of all edible plants. I do not know whether or how this latter operation is visualized. I suppose it is not meant to be in any literal-minded way. While birth, then, is an element in both Greek and Sumbanese creation stories, it appears to function in quite distinct ways in each of these traditions ${ }^{19}$.

In comparing a Sumbanese myth with Greek stories, I am aware of juxtaposing two traditions that have no known points of historical contact ${ }^{20}$. This is a perfectly valid approach, which may elicit general properties of mythic discourse, but it is also fruitful to compare Greek myths with narratives current in the eastern Mediterranean world

17 See Iliad, XIV, 200-07, 246; WEST, The Orphic Poems (above, n. 14), p. 184-90.

18 Cf. Thales, 11 A 12 (ARISTOtLe, Metaphysics, $983 \mathrm{~b} 6$ sq.) and 13 (Simplicius in Physica, 23, 21 sq. Diels) Diels-Kranz; ANaximenes, 13 A 5 (Simplicius in Physica, 24, 26 sq. Diels), 6-8.

19 Peter Rose of the Department of Classics at Miami University in Ohio has suggested to me that the double motivation of heroes in the Homeric epics, part naturalistic, part inspired by what E.R. DoDDs called the "psychic intervention" of the gods, is analogous to the parallel operation of genealogical sequence and natural causation.

20 M. SAHLins, The Stranger-King or Dumézil among the Fijians, in Journal of Pacific History, 16 (1981), p. 107-132, suggests analogies between IndoEuropean and Polynesian conceptions of sovereignty; Joel KuIPERs has pointed out to me that Arab traders might have served as a conduit for cultural exchange between India and Indonesia. 
among the Babylonians, say, or Egyptians, where there is evidence of influence or dissemination among peoples of different origin dwelling in close proximity to one another. Now, a strong case can be made that Greek creation narratives as well as stories of the succession of kingship among the gods contained in Hesiod were influenced at some time or other by the Babylonian creation myth related at harvest time and known, from the first two words in the tale, as Enuma elish, or "When on high ${ }^{21}$ ". This tale tells of the bitter struggles among the gods, and how the world was formed from the body of Tiamat, goddess of the salt or bitter waters, after she was defeated by Marduk. I quote a brief section : "Then Marduk considered Tiamat. He skimmed spume from the bitter sea, heaped up the clouds, spindrift of wet and wind and cooling rain, the spittle of Tiamat. With his own hands from the steaming mist he spread the clouds. He pressed hard down the head of water, heaping mountains over it, opening springs to flow : Euphrates and Tigris rose from her eyes, but he closed the nostrils and held back their springhead. He piled huge mountains on her paps and through them drove waterholes to channel the deep sources; and high overhead he arched her tail, locked-in to the wheel of heaven; the pit was under his feet, between was the crotch, the sky's fulcrum. Now the earth had foundations and the sky its mantle ${ }^{22}$ ".

The resemblances between this story and the Sumbanese myth are obvious. Contrast Hesiod's account in the Theogony 116-38: "First came the Chasm; and then broad-breasted Earth, secure seat for ever of all the immortals who occupy the peak of snowy Olympus; then misty Tartara in a remote recess of the broad $\neg$ pathed earth; and Eros, the most handsome among the immortal gods, dissolver of flesh, who overcomes the reason and purpose in the breasts of all gods and all men. Out of the Chasm came Erebos and dark Night, and from Night in turn came

21 See WEST, Theogony (above, n. 11), p. 22-24; R. MONDI, Greek Mythic Thought in the Light of the Near East, in L. EDMUNDS (ed.), Approaches to Greek Myth, Baltimore, 1990, p. 160-189, with references.

22 J.B. Pritchard (ed.), Ancient Near Eastern Texts, Princeton, 1955², p. 93-94. A Daoist cosmogony speaks of the demiurge Pangu, «who, at his death, transformed his body. His repiration yielded the clouds and the wind, his voice the thunder, his limbs the four extremities of the world, his left eye the sun, his right eye the moon, his internal organs the five peaks.... And all the vermin he carried, roused by the wind, metamorphosed into humans"; cited and translated by J. LÉvi, The Body : The Daoists' Coat of Arms, in M. FeHER et aliae, Fragments for a History of the Human Body, Part 1, New York, $1989=$ Zone 3, p. 109, from "Yuanqi lun", in "Yunji qiqian» 56, 1a-b, Daozang, Shahnghaai, 1924, p. 677-702. 
Bright Air and Day, whom she bore in shared intimacy with Erebos. Earth bore first of all one equal to herself, starry Heaven, so that he should cover her all about, to be a secure seat for ever for the blessed gods; and she bore the long Mountains, pleasant haunts of the goddesses, the Nymphs who dwell in mountain glens; and she bore also the undraining Sea and its furious swell, not in union of love. But then, bedded with Heaven, she bore deep-swirling Oceanus, Koios and Kreios and Hyperion and Iapetos, Thea and Khea and Themis and Memory, Phoebe of gold diadem, and lovely Tethys. After them the youngest was born, crooked-schemer Kronos, most fearsome of children, who loathed his lusty father ${ }^{23}$ ». Earth here is conceived of as a progenitor, and in conformity with this role, she is properly personified. Thus Martin West, whose translation I have reproduced, prints Earth ( $\Gamma \alpha \hat{\imath})$ with a capital letter. When he departs from this convention in the description of "misty Tartara in a remote recess of the broad-pathed earth", it is because Hesiod is evidently speaking of earth as the ground ( $\chi$ Oovós, 119), and not as the deity that represents it. Earth gives birth ( $\gamma \varepsilon$ iv $\alpha \tau$, 129) to Mountains (capital "M" in West's version); her breasts do not become mountains. In a word, Hesiod gives us a theogony, not a cosmogony; the difference between the two is implicit in his text, and leaves the room we spoke of earlier for a materialistic version of creation to supplement the mythic genealogy of the gods ${ }^{24}$. There would seem to be a difference between the Hesiodic tradition and its near-eastern congener corresponding to that which we observed between Greek creation stories and the Sumbanese tale related at the beginning of this paper.

It is also profitable to look to the roots of the Greeks' tradition in their own past as a social, or at least linguistic, group. Just as it is possible to reconstruct the common source of Greek and kindred languages in an Indo-European forebear, so too one may trace at least some Greek myths back to an original set of Indo-European narratives, which lie behind versions that are identifiably cognate in India, Italy, Persia, Germany,

23 Translation that of WEST (above, n. 11), p. 6-7; paragraphing altered.

24 As West remarks, "When your gods include the Heaven and the Earth, a theogony entails a cosmogony", Theogony (above, n. 11) ad 116-53, and there would seem to be more of a confusion in this earliest phase of creation between the god and the element she or he represents, for example in the case of the sky, mountains or sea. And yet HESIOD seems to keep the two aspects distinct in each case. Thus, Earth bore (egeinato, 127) Uranus, so that he might be the seat of the gods; she bore the Mountains, as the pleasant chambers of the Nymphs; she gave birth to sea ( $\pi \varepsilon \dot{\varepsilon} \alpha \gamma \circ \zeta, 131$ ), who was Pontus (132). Parturition produces a god, not an element as such. 
Russia, or the Celtic world. Now, it is curious that, according to the school of Georges Dumézil, which has generated the most detailed and sophisticated theories in this field, Greek mythology constitutes an exception among the several traditions that share the Indo-European heritage ${ }^{25}$. In the others, there are myths that betray a certain fundamental set of traits in common, based on a tri-partite division of society into three distinct orders or functions - the kingly function, the warrior function, and the productive function, which embraces all aspects of growing or making, including sexual reproduction. In Greece, on the contrary, with its extraordinarily fecund mythological tradition, there seem to be only peripheral vestiges of the Indo $\neg$ European heritage ${ }^{26}$. This is all the more surprising in that the Greek language is one of the more faithful witnesses to the grammar and forms of IndoEuropean.

The reasons why this is the case are various, and doubtless include the effect of Near Eastern and other non - Indo-European influences on Greek mythology 27 . But the development of the Greek polis or city-state brought on to the scene a new social formation, in which the functions of ruler, fighter, and worker were collapsed into the single figure of the citizen, ideologically positioned as the head of an individual household, and bound to the members of other Greek cities by a common language, sense of ethnic identity, and a set of religious practices (cf. Hdt., VIII, $144,2-3)$. In the myths, the gods were correspondingly imagined in the first instance as a family, loosely on the model of the oikos, and local as well as foreign deities were associated in a complex kinship stemma ${ }^{28}$. Such a conception may have contributed to both the anthropomorphism and the genealogical character of Greek mythology.

25 See the cautious statement of Greek exceptionalism in J. FALAKY NAGY, Hierarchy, Heroes, and Heads : Indo-European Structures in Greek Myth, in L. Edmunds (ed.), Approaches to Greek Myth, Baltimore, 1990, p. 204-06, with bibliography.

26 There is an analogy between this tripartite division of social roles and PLATO's prescription for the ideal republic, and indeed it has been suggested that PLATO derived his system from his close observation of the social and ideological life of Crete, where, it is alleged, the old Indo-European tradition continued to thrive; see B. SERGENT, L'utilisation de la trifonctionnalité d'origine indoeuropéenne chez les auteurs grecs classiques, in Arethusa, 13 (1980), p. 233-278.

27 See C. Scott LitTleton, The Problem that was Greece: Some Observations on the Greek Tradition from the Standpoint of the New Comparative Mythology, in Arethusa, 13 (1980), p. 152-155.

28 See Jenny STRAuss ClAY, The Politics of Olympus : Form and Meaning in the Major Homeric Hymns, Princeton, 1989, p. 9-11. 
III

There are two further features of Greek mythology to be elicited from a comparison with the Sumbanese tale about the rat and his wife. To begin with, the reader may have been wondering just why a human woman was betrothed to a rat. The answer is that she was the youngest of fifteen royal children, eight sisters and seven brothers. Each of the brothers was married to one of the sisters. The last sister, however, was without a mate, and thus was available to be wooed by the rat (who first appeared, it will be recalled, in human form). In the story from Sumba, as I understand it, the point is that only the sister who escapes from an incestuous marriage will prove ultimately fertile, and give birth to the foodstuffs that will nourish mankind ${ }^{29}$. At stake in the creation myth is breaking out of the closed circle of the immediate family, crossing boundaries, encountering the foreign. There is a tense dialectic here between the domestic or familiar on the one hand, and the external or strange on the other. Each is exaggerated. The domestic is somehow too close, resulting in incest; the outsider is too foreign, assuming the form of a member of the different species.

Now, there is clearly something of an analogy to this tale in the marriages between the daughters and sons of Aeolus, as narrated in Homer's Odyssey (X, 1-12). In that episode, however, there is a perfect match of brothers and sisters, and thus no supplementary sibling to provide the occasion for an exogamous union. I should like, very tentatively, to suggest that the opposition between incest and bestiality implicit in the Sumbanese tale does not in general inform Greek mythology. More specifically, I believe that Greek myths, as we know them, do not indicate any particular preoccupation with brother-sister incest as such. Among the gods, it is a fact of life, as in the case of Cronus and Rhea, or Zeus and Hera. Virgil perhaps saw something odd or paradoxical in the peculiar circumstance that Juno is simultaneously spouse and sister to Jupiter, soror et coniunx (Aeneid, I, 46-47); Homer betrays no apparent anxiety about the nature of their relationship. Further, the fact of sibling incest among the gods has neither good nor bad consequences in and of itself : no difference between the issue of Zeus and Hera, for example, and the offspring of Zeus's adulterous affairs, e.g. with Leto or Maia, is marked in Greek myth.

29 KUIPERS agrees that this is a plausible interpretation of this aspect of the myth. 
What is more, the Greeks were in practice rather more tolerant of marriages between close relations that we are, or than the Romans were for that matter. As Roger Just remarks in his study of women in Athenian society : "One of the more striking features of genealogical material derived from fifth- and fourth- century Attic sources is the frequency of marriage between extremely close $\mathrm{kin}^{30}$ ». In particular, marriages between half $\neg$ brothers and sisters were permitted if the pair were not of the same mother, despite the fact that lineage was reckoned by the father. This partial relaxation of the rule against endogamy within the oikos or family may in part account for the extraordinary circumstance that among the Greeks who settled in Egypt, marriages between full brothers and sisters seem to have been commonplace, and even regarded as desirable. It is inconceivable that a social group in which sibling relations were a deep source of incest anxiety should have undergone a conversion in its practices within at most a few generations, even in the context of founding a new city. Yet the papyrological evidence on this score is quite unambiguous, and indeed makes the Alexandrian Greeks unique, it would appear, among the populations of the world in this respect ${ }^{31}$. Something in the new Greek order seems to have brought about a reduction in the anxiety associated with marriage between close kin and siblings in particular. It was not the crucial boundary to be worried over in myth and ideology 32 .

Thus, Plato, in the scheme that he proposes to destroy conjugal exclusivity among the ruling classes in the Republic (V, 457b-66d), is careful to build in a safeguard against incest between natural parents (or grandparents) and children, since cross-generational unions are

30 R. Just, Women in Athenian Law and Life, London, 1989, p. 76. The value of marriages between kin in cementing alliances is taken for granted by ISAEUS, VII, 12.

31 See Keith Hopkins, Brother-Sister Marriages in Roman Egypt, in Comparative Studies in Society and History, 22 (1980), p. 303-354.

32 Charges of incest, like the accusation that a rival was a bastard or nothos, were commonplace weapons in political conflicts between powerful families, and any rumored violation of convention or of the legal code would serve. Thus, slander based on brother-sister incest (e.g., LYSIAS, XIV, 28-29) is retailed alongside other deviations such as father-daughter incest (LYSIAS, XIV, 41); see Cheryl Anne Cox, Incest, Inheritance and the Political Forum in Fifth-Century Athens, in CJ, 85 (1989), p. 34-46, esp. p. 39-40. The very frequency with which the charge is leveled by orators and comic poets suggests that it did not provoke quite the horror that attaches to such an accusation today. But such evidence does not assist us in discriminating the reaction to sibling relations from the taboo associated with cross-generational incest. 
disallowed (461b-c), but is remarkably casual about the danger of sibling incest, which under the circumstances he envisages was rather likely to occur: "The law will allow brothers and sisters to marry, if the lot falls out this way and the Pythian priestess agrees" $(461 \mathrm{e})^{33}$. One might argue that Plato played down the irregularity of such unions precisely because they were more or less inevitable under his system, yet Aristotle, who had no such compunctions in his criticism of Plato's communalism, pretty much ignores the problem of incest between brother and sister, centering his concern rather on the possibility of homosexual relations between brothers :

It is also strange, having made sons in common, to eliminate only

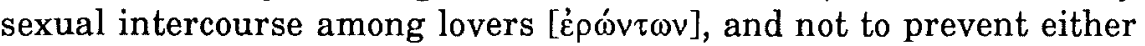
love [épâv] or the other practices which are most unseemly on the part of a father toward a son or a brother toward a brother, since even love ['ं $\rho \hat{\alpha} v$, i.e., a passionate or sexual attraction] alone is such. It is also strange to eliminate sexual intercourse for no other reason, but that the pleasure becomes excessively strong, and to think it makes no difference that a father or a son [feels it], or brothers for one another. (1262a32-40)

In the Laws, Plato puts the shame attached to sibling relations on a par with cross-generational incest, noting that even lawless people will refrain from intercourse with a brother or sister, irrespective of whether they are attractive (838a5-9), because we are all constantly told that such associations are abominable, whether in conversation or in the theater, where «an Oedipus, a Thyestes, or a Macareus, who secretly slept with his sister, is seen spontaneously inflicting death upon himself as the punishment for his crime» (838c5-7). But, as Roger Just remarks, Plato seems a few lines later to restrict the actual effectiveness of the taboo on incest to relations with parents (839a4-5).

The incest between Macareus and his sister Candace was an element in the Aeolus of Euripides, which survives only in fragments : when he learns what has happened, Aeolus evidently sends his daughter a sword with which she slays herself, and Macareus commits suicide with the same weapon (Stobaeus, Flor., 64, $35 \mathrm{Nauck}^{2}$, p. 366). A new hypothesis, edited by E.G. Turner in Pap. Oxy., 27 (1962) 2457, indicates that the king cast lots in order to distribute his sons among his

33 See J. AdAM, The Republic of Plato, revised by D.A. REes, ad loc., Cambridge, 1963. 
daughters ${ }^{34}$. Even without this evidence, fr. 17 Nauck makes it reasonably clear that Aeolus paired off brother and sister in this way :

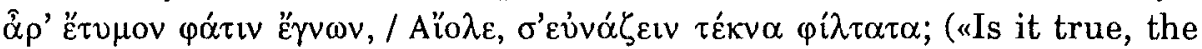
rumor I've learned, Aeolus, that you are marrying your own children [sc. to one another]" ?). It is thus reasonably clear that Aeolus was not angry with Macareus and Candace simply on account of incest. It is impossible to reconstruct exactly how the theme was handled, but it is at least plausible to suppose that the passion between Macareus and Candace in some way violated Aeolus' wishes concerning the intended marriages between his sons and daughters, perhaps because the lot had assigned the partners differently ${ }^{35}$. The focus of the play, then, may very well have been on the disobedience of Macareus and Candace, motivated by their passion for one another, rather than on the fact of incest per $\mathrm{se}^{36}$.

Aeschylus' Suppliant Women, the first play of a trilogy on the Danaids, represents the daughters of Danaus fleeing from marriage with their cousins, the sons of Aegyptus. The motive for their repugnance at the union is not entirely clear : it cannot be a horror of incest as such, since the degree of relationship was not a prohibited one in Athens ${ }^{37}$. What is more, the resolution of the trilogy celebrates the refusal of one of the Danaids, Hypermestra, to participate in the plot to

34 On the lot-casting scene, see W.T. MACCARY, The Comic Tradition and Comic Structure in Diphilos' Kleroumenoi, in Hermes, 101 (1973), p. 198-299. The play was much parodied, e.g. by ARISTOPHANES in his posthumous Aiolosikon, ANTIPHANES in his Aeolus (where he indicated that Macareus was drunk when he violated Canace), Eriphos in an Aeolus.

35 It is possible that Aeolus himself had conceived a passion for Candace, cf. fr. 23 26 Nauck; but MACCARY (above, n. 34), p. 199 rightly, I think, dismisses this al ternative.

36 It is commonly supposed that the Aeolus who is the father of Macareus and Candace (and many other children as well) is entirely distinct from the figure of the same name who controls the bag of the winds in the Odyssey, though the two are sometimes confused in the tradition; cf., for example, H.J. Rose in the Oxford Classical Dictionary, Oxford, $1970^{2}$, s.v. Can this really be a case of accidental assimilation? It would be well, I think, to allow for the possibility that the poet(s) of the Odyssey invented a version that purged the tragic features attaching to the marriage of Aeolus' sons and daughters.

37 Cf. K. DowDEN, Death and the Maiden : Girls' Initiation Rites in Greek Mythology, London, Routledge, 1989, p. 154 : «The source of the hostility between the Danaids and the sons of Aigyptos is unclear. The reluctance of the Danaids to marry is a premiss, to be accepted without explanation so that the story may begin». DOWDEN interprets the myth as the narrative residue of an original initiatory ritual for adolescent girls. 
murder the suitors. The tale thus works in a sense precisely opposite to the Sumbanese creation story : there is an equal rather than an unequal number of male and female cousins; they are potentially rather than actually paired in marriage; and the successful union occurs between a couple whose kinship connection is not different in degree from that of their brothers and sisters ${ }^{38}$.

This is not the place to pursue speculations on the ways in which the oikos - or household - based structure of the classical Greek polis may have contributed to a relaxation of the anxieties surrounding brothersister incest. The topic of sibling incest among the Greeks seems to me a fascinating problem that is still very much in need of fresh study and interpretation.

Finally, the reader may also have been wondering just how the rat killed his wife, after he became enraged at her inability to join him in his hole - an incapacity for which he himself was partly responsible, since it was he who made her pregnant. The answer is that he cut her throat, though this seems to be a relatively unimportant detail in the narrative, and is not necessarily mentioned at each recital. Now, in Greek mythology, I venture to say, the question of means and motive would have loomed larger. The Greeks would have been disposed to elaborate on the tale, assign reasons, righteous or otherwise, for the rat's behavior, give the wife more of a personality than she achieves in the story from Sumba. Certainly, this would have been the case if the tale of the rat and his wife had been elaborated, for instance, as a tragedy.

This last seems a comical suggestion, no doubt. A marriage between a woman and a rat (other than the type of rat that Jason was, in his relationship to Medea) is not the stuff of Greek tragedy. Monstrous

38 Giulia Sissa, Greek Virginity, transl. A. GoldHAMmer, Cambridge MA, 1990, p. 171 , treats the Danaids as «ingrates who sustained the emptiness of an unfillable belly", and who, because of their refusal of marriage, uembodied the utmost possible incompleteness of the female body". In Hades, where they are required to carry leaky vessels, they suffer condign punishment : «It was as if an unstanchable flow kept the mouths of their wombs open and the lips of their genitals apart». Cf. PAUS., X, 14, 1-4 on Tennes, who, on suspicion of designs upon his step-mother, was cast into a chest with his sister; coins of Tenedos seem to treat her as his consort : N.M. Holley, The Floating Chest, in JHS, 69 (1949), p. 40 (I am grateful to my colleague Adele SCAFURo for calling my attention to this story). 
beings can and do appear on stage. The Prometheus Bound, whoever was its author, brought Io on stage while she was still part cow, for example. But Greek tragedy inevitably focussed on the emotional and personal content of a mythic narrative. The tale alone was the bare scaffolding, the skeleton of the real substance of the drama. To write a tragedy about the rat and his wife, one would need to endow both with a good deal more of human sensibility.

It may seem unfair of me to bring in Greek tragedy as a point of comparison with Sumbanese mythology. It would appear more appropriate to match myth with myth, and not compare two quite distinct forms or genres, evidently to the disadvantage of the Sumbanese narrative. Leaving aside the question of advantage, however, I think it may not be entirely wrong to take tragedy as an example of Greek mythology. It is characteristic of our sources for Greek myths, however early we trace them, that they are texts designed for performance before an audience ${ }^{39}$. They are not harvest songs, like the story of the rat and his wife, or the Babylonian Enuma elish. They are not recited in specific ritual contexts. In some measure or other, they have achieved, by the time of Hesiod and Homer, a certain independence as stories, subject to embellishment, elaboration, psychologization. In this, tragedy was of a piece with epic, for example, and it is no accident that Aeschylus could refer to his own dramas as crumbs from the banquet of Homer, or that Aristotle could cite the Iliad and Odyssey as examples of wellconstructed narratives, on a par with the best plays. The fact is, I believe, that we have no stories from ancient Greece corresponding to the recitation of the creation myth among the Sumbanese.

Nor is this merely, I suspect, an accident of transmission, so that only those versions committed to writing survived, while more elementary narratives, handed down orally, perished for want of a recorder. If there had been someone to take down the tales of the ancient Greeks, as Joel Kuipers was there to transcribe the story of the rat and his wife, he or she would not necessarily have found more authentic, more "mythical" repositories of narratives than those that have survived in

39 I am stressing here the performative aspect of Greek myth as essential to its developed narrative character, as opposed, for example, to the use of writing versus oral transmission; for a balanced discussion of the latter distinction, see Carlo BRILLANTE, History and the Historical Interpretation of Myth, in Ed. Lowell (ed.), Approaches to Greek Myth, Baltimore, 1990, p. 112-16. The performative character of the Homeric epics and hymns was, I think, closely bound up with the synthesis of local mythological traditions into a panhellenic corpus; see CLAY (above, n. 28), p. 268-270. 
the form of epic, didactic literature, tragedy, lyric poetry, histories, handbooks, commentaries, and the like. The Babylonians wrote down a version of their creation story that preserved the features of a tale recited at the harvest. They have given us a myth which in important respects resembles that of the Sumbanese, or resembles it in ways that the Greek stories do not. The Greeks handed on their myths in a different form, and this too is part of their nature from the beginning - if, as Herodotus says, Homer and Hesiod were in some sense the beginning of Greek mythology. There is no story of Medea and Jason without her feelings of outraged pride, any more than there is a tale about Penelope that fails to include her personal loyalty to Odysseus.

At the level of the bare-bones structure, we can compare any number of narratives and make them out to be essentially one and the same, in essence. In the story of Medea and Jason, like that of Ariadne and Theseus, for example, a hero ventures on a dangerous mission by ship to a foreign land, and is assisted in completing a series of tasks by a princess who follows him home, against the wishes of her father. In both cases, the hero later abandons his bride, who, in her resentment, curses him. We might even note that both Ariadne and Medea violate kinship bonds by contributing to the death of a brother, in Medea's case the boy Apsyrtus, in Ariadne's her half-brother, the Minotaur - for that, as Catullus noticed, is what he is ${ }^{40}$. We can, if we like, read these two stories as versions of a single mytheme, and imagine their source in a ritual associated with a mother goddess, or whatever. But that is not what Ariadne and Medea were for the Greeks. They were two distinct figures, different in motives, in responses, in all sorts of particulars. Given the medium in which their stories were related, that is, poetry, fiction, quasi-historical texts, and the like, this is no surprise. My point is that Greek mythology cannot, perhaps, be separated from the medium through which we know it. That is part of its nature. In this respect too, it differs from at least certain other mythic traditions.

The hexameter tradition of Greek mythology, as it took shape and was codified at the hands of bards like Homer and Hesiod, gave expression simultaneously to the new ideals of the polis, with their roots in the autonomous household or oikos, and the panhellenic vision of a single Greek culture. This articulated body of myths, which selfconsciously set itself apart from prose forms like the fable with its own narrative conventions, installed a radical distinction between human

40 Cf. Catullus, 64, 149-51; D. Konstan, Catullus' Indictment of Rome : The Meaning of Catullus 64, Amsterdam, 1977, p. 68-69. 
beings and beasts based on the capacity for language; differentiated between nature and the divine through strictly genealogical or theogonic versions of creation and evolution; was sympathetic to an endogamous structure of relations within the city and played down any inherited taboos against brother-sister incest; and gave literary expression to these motifs in the context of artistic or dramatic performances, rather than in connection with ritual practices. Taken together, these features, I think, constitute a part of what is Greek about Greek mythology.

Brown University

David KONSTAN

Providence RI 02912

U.S.A 